\title{
Serum Concentrations of Strontium, Lead, Nickel, Vanadium and Aluminum in Horses
}

\author{
Saeed Nazifi ${ }^{1 *}$, Neda Eskandarzade ${ }^{2}$, Mahsa Khosravi ${ }^{1}$, Maryam Haddadi $^{1}$ and Mojtaba Rahsepar ${ }^{1}$ \\ ${ }^{1}$ Department of Clinical Studies, School of Veterinary Medicine, Shiraz University, Shiraz, Iran \\ ${ }^{2}$ Department of Basic Sciences, School of Veterinary Medicine, Shahid Bahonar University, Kerman, Iran
}

\begin{abstract}
Providing data on the serum concentration of some important heavy metals in horses of different age and sex is an indicator of short-term exposure and also help to understand influence of these factors in metals intoxication. We reported serum concentrations of some elements in healthy horses and assessed any relationship with age and sex. Fifty-three samples from horses were analyzed by atomic absorption. Mean serum concentrations $(\mu \mathrm{g} / \mathrm{ml}) \pm \mathrm{SD}$ values for strontium were $(0.25 \pm 0.15)$, vanadium $(0.20 \pm 0.02)$, aluminium $(0.71 \pm 0.16)$, nickel $(0.10 \pm 0.08)$ and lead $(0.09 \pm 0.04) \mu \mathrm{g} / \mathrm{ml}$. No significant correlations were noted between measured elements with age, however, a significant correlation was detected between age with concentration of lead $(P<0.05)$. We concluded that older horses had more ability to absorb this element from their environment, or ability to detoxify lead decreased with increase in age.
\end{abstract}

Keywords: Strontium; Aluminum; Vanadium; Nickel; Lead; Horse

\section{Introduction}

Heavy metals are widely spread in human and animal environments by sources like industries and can cause some biological malfunctions. For example, absorbed $\mathrm{Ni}$ changes membrane properties and balance of oxidation/reduction systems. It has great affinity for cellular structures like chromosomes and its toxicity is teratogenic and carcinogenic [1-3]. This element is excreted mainly via the urine and to a lower extent in breast milk. Milk and dairy products are one of the main contributors to the chronic dietary exposure to nickel (Ni) in humans [4]. Lead $(\mathrm{Pb})$ has been one of the most common toxicants encountered in veterinary practice and peripheral neuropathy, intermittent colic, and mild anemia are common features of acute toxicosis with this element in general [5]. Equines are food and milk-producing animals in many countries, therefore determining status of toxicants in equine biological components is relevant to human health, and therefore should not be underestimated [6,7]. However, the toxic doses of elements in animals have not been known yet because there is disagreement between results of published studies, and still the physiological mechanisms involved in mineral poisoning are also not yet understood. Finding correlations between some physiological parameters such as age and level of elements accumulation in blood helped underestanding this criteria.

Although there are several studies which revealed that quantities of metals in horse biological components were good bio-indicator for environmental pollution and nutritional status [8-11] there is still limited reference about influence of age and sex on blood elements concentrations in these animals. This study was conducted to evaluate the amounts of some important elements such as strontium ( $\mathrm{Sr}$ ), aluminum $(\mathrm{Al})$, vanadium $(\mathrm{V})$, nickel $(\mathrm{Ni})$ and lead $(\mathrm{Pb})$ in the blood of horses of different age and sex in Shiraz which could be used in disease assessment of human and equine and better understanding the physiological parameters attributed to these elements intoxication.

\section{Materials and Methods}

This study was conducted on a group of 53 horses which belonged to two farms around Shiraz. The horses were considered healthy based on physical examination. There were 22 males, 31 females. Animals were divided into 3 groups regarding age $<5$ years $(\mathrm{n}=16), 5-10$ years $(\mathrm{n}=26),>10$ years $(\mathrm{n}=11)$.

\section{Sampling}

Blood samples were taken aseptically from jugular veins, placed into tubes without any anticoagulant and put in the water-bath at $37^{\circ} \mathrm{C}$ to coagulate. After clotting, the samples were centrifuged and sera were obtained. Samples were kept at $-20^{\circ} \mathrm{C}$ until chemical analysis.

\section{Animal ethics}

The experiment was performed under the approval of the state committee on animal ethics, Shiraz University, Shiraz, Iran (IACUC no: 4687/63). Also, the recommendations of European Council Directive $(86 / 609 / \mathrm{EC})$ of November 24,1986 , regarding the protection of animals used for experimental purposes were considered.

\section{Preparation of the samples}

The serum samples were analyzed by $700 \mu$ hydropercloric acid $98 \%$ and nitric acid $65 \%$ added to $300 \mu$ of serum and kept for $16-20$ hours in $80^{\circ} \mathrm{C}$ water-baths. The prepared samples were analyzed by atomic absorption spectrometry (Shimadzu AA-670, Japan).

\section{Measurement of the elements}

Trace elements were analyzed by flame and air $-\mathrm{C}_{2} \mathrm{H}_{2}$ for $\mathrm{Pb}, \mathrm{Sr}$, $\mathrm{Ni}$ and $\mathrm{N}_{2} \mathrm{O}-\mathrm{C}_{2} \mathrm{H}_{2}$ for $\mathrm{Al}$ and $\mathrm{V}$. Primarily, the atomic absorption was set to a special wavelength, $217 \mathrm{~nm}$ for $\mathrm{Pb}, 232 \mathrm{~nm}$ for $\mathrm{Ni}, 309.3 \mathrm{~nm}$

${ }^{*}$ Corresponding author: Dr. Saeed Nazifi, Professor of Veterinary Clinical Pathology, Department of Clinical Studies, School of Veterinary Medicine, Shiraz University, Shiraz, Iran, Tel: +987112286940; Fax: +987112286950; E-mail: nazifi@shirazu.ac.ir

Received June 27, 2017; Accepted July 21, 2017; Published July 22, 2017

Citation: Nazifi S, Eskandarzade N, Khosravi M, Haddadi M, Rahsepar M (2017) Serum Concentrations of Strontium, Lead, Nickel, Vanadium and Aluminum in Horses. J Vet Sci Technol 8: 457. doi: 10.4172/2157-7579.1000457

Copyright: (c) 2017 Nazifi S, et al. This is an open-access article distributed under the terms of the Creative Commons Attribution License, which permits unrestricted use, distribution, and reproduction in any medium, provided the original author and source are credited. 
for $\mathrm{Al}, 460.7$ for $\mathrm{Sr}$ and $318.4 \mathrm{~nm}$ for $\mathrm{V}$; the machinery was calibrated by injecting 5-6 standard solutions with different concentrations in normal range of each element, solutions were injected to the machinery and element concentration was measured in $\mu \mathrm{g} / \mathrm{ml}$.

\section{Statistical analysis}

Statistical analysis was performed using SPSS software (version 18). The effect of age on the concentration of the analyzed elements in the serum of horses was determined by Kruskal-Wallis $\mathrm{H}$ except for $\mathrm{Ni}$, which was analyzed by one-way ANOVA. The effect of sex on the concentration of the analyzed elements in the serum of horses was determined by Mann-Whitney $\mathrm{U}$ test except for $\mathrm{Ni}$, which was analyzed by Independent-Samples t-test. $\mathrm{P}<0.05$ was considered as statistically significant. The relationship between the amount of serum concentrations of individual elements and different age and sex was calculated using Spearman correlation analysis.

\section{Results and Discussion}

Serum concentration of analyzed elements $\left(\mu \mathrm{g} . \mathrm{mL}^{-1}\right)$ in different categories with regard to sex and age are presented in Tables 1 and 2. All heavy metals evaluated were present in the blood of the horses and serum concentration of the analyzed elements followed the order $\mathrm{Al}>\mathrm{Sr}>\mathrm{V}>\mathrm{Ni}>\mathrm{Pb}$. The different age and sex studied here did not influence the serum contents of $\mathrm{Ni}, \mathrm{Al}$ and $\mathrm{V}(\mathrm{P}>0.05)$ although significant correlation between age and concentration of $\mathrm{Pb}$ was detected $(\mathrm{P}<0.05)$.

\section{Strontium $(\mathrm{Sr})$}

In our study $\mathrm{Sr}$ concentration in females $(0.3 \pm 0.02 \mu \mathrm{g} / \mathrm{ml})$ was more than in males $(0.18 \pm 0.03 \mu \mathrm{g} / \mathrm{ml})$ which was not consistent with a study done by Pablack et al. [12] that showed no gender differences in $\mathrm{Sr}$ concentration existed in liver and kidney of horses. The reason for this difference is not clear and no information is available in this regard. So, more investigations are required for better understanding of this finding. According to Table 2, No significant correlation between concentrations of Strontium with age was seen which was in agreement with a study carried out by Pablack et al. [12] which showed no agedependent differences in Strontium concentration in liver and kidney of horses. Although Sr concentration in animals with age more than 10 years old $(0.20 \pm 0.07 \mu \mathrm{g} / \mathrm{ml})$ was lower than horses with age 5-10 years $(0.27 \pm 0.02 \mu \mathrm{g} / \mathrm{ml})$ and $<5$ years old $(0.25 \pm 0.02 \mu \mathrm{g} / \mathrm{ml})(\mathrm{P}<0.05)$. This is probably because of higher absorption of strontium from the intestines of younger horses than adults. In the body, strontium behaves very much like calcium and will accumulate in bones. Excess stable strontium causes problems with growing bone. For this reason, children are more susceptible to the effects of stable strontium than adults who have mature bone [13]. Studies in humans suggested that the elimination rate of strontium is strongly affected by age and sex, due to differences in bone metabolism [14].

\section{Lead $(\mathrm{Pb})$}

As lead is an important environmental contaminant, in this context, reports on lead poisoning exist for horses and other livestock in contaminated areas [15-17]. Pourjafar and his coworkers in 2008 confirmed usability of horse hair as a test bio-indicator for $\mathrm{Pb}$ envirmental pollution [9]. However, there was no decisive agreement on intoxication of horses by this heavy metal. For example, in a study carried out in India with 288 horses from three different areas (industrial, highway adjacent and rural zone) no clinical signs associated with intoxication by lead were detected in the studied animals [18] On the other hand, a study conducted with horses living on farmland in the vicinity of non-ferrous metal smelters in China showed signs of intoxication by lead in horses [19]. Lead concentrations in the blood and organs of horses indicated lead concentrations in equine by-products. The lead toxicity values in the blood for farm animals have been always lower than those in humans [20] and in horses, the concentration of $0.25 \mu \mathrm{g} \mathrm{mL} \mathrm{m}^{-1}$ is accepted as maximum limit [21]. According to our results, contents of $\mathrm{Pb}$ in $100 \%$ of samples analyzed present levels below the detection limits. As shown in Table 1, in males, $\mathrm{Pb}$ concentration $(0.1 \pm 0.00 \mu \mathrm{g} / \mathrm{ml})$ was significantly higher than females $(0.08 \pm 0.01 \mu \mathrm{g} / \mathrm{ml})$. As shown in Table 2, although all of the horses used here were in the same environment, there is significant increase in $\mathrm{Pb}$ concentration in group with more than 10 year-old horses $(0.1 \pm 0.00 \mu \mathrm{g} / \mathrm{ml})$ compared to the other two groups. Also, $\mathrm{Pb}$ concentration increased with increasing in age, so there is a correlation between age with concentration of $\mathrm{Pb}(\mathrm{P}<0.05)$. It seemed that ability to detoxify lead decreased with increase in age or older horses had more ability to absorb this element from their environment, however, further investigations are needed to confirm this hypothesis. Present data was in agreement with a research done by Rudy which indicated that contamination of meat of cattle by $\mathrm{Pb}$ clearly depends on the age of these animals and older cattles had more $\mathrm{Pb}$ concentrations [22] But our finding is not in agreement with Asano et al. [23] who reported that there was no age-dependent correlation in $\mathrm{Pb}$ concentration of mane hair in male and female racing horses. In present study, the mean serum $\mathrm{Pb}$ concentration in 53 horses was $(0.09 \pm 0.04) \mu \mathrm{g} / \mathrm{ml}$ which was lower than the values reported by De Souza et al. [24] $(1.058 \mu \mathrm{g} / \mathrm{ml})$.

\section{Nickel (Ni)}

If we consider presence of high amount of $\mathrm{Ni}$ in legumes such as

\begin{tabular}{|c|c|c|c|c|}
\hline Sex & $\begin{array}{c}\mathbf{N i} \\
\left(\boldsymbol{\mu g} \mathbf{~ m L}^{-1}\right)\end{array}$ & $\begin{array}{c}\mathbf{P b} \\
\left(\mu \mathbf{m ~ m L}^{-1}\right)\end{array}$ & $\begin{array}{c}\mathbf{S r} \\
\left(\boldsymbol{\mu g} \mathbf{~ m L}^{-1}\right)\end{array}$ & $\begin{array}{c}\mathbf{A a} \\
\left(\boldsymbol{\mu g} \mathbf{~ m L}^{-1}\right)\end{array}$ \\
\hline Male & $0.096 \pm 0.01$ & $0.1 \pm 0.00^{\mathrm{a}}$ & $0.18 \pm 0.03^{\mathrm{a}}$ & $0.72 \pm 0.03$ \\
\hline Female & $0.115 \pm 0.01$ & $0.08 \pm 0.01^{\mathrm{b}}$ & $0.30 \pm 0.02^{\mathrm{b}}$ & $0.20 \pm 0.00$ \\
\hline
\end{tabular}

Values that have a different superscript $(a, b)$ differ significantly from each other $(P<0.05)$.

Table 1: Concentrations $(\mu \mathrm{g} / \mathrm{ml})$ of strontium ( $\mathrm{Sr})$, aluminum (Al), vanadium $(\mathrm{Va})$, nickel $(\mathrm{Ni})$ and lead $(\mathrm{Pb})$ in the serum of horses, depending on the sex of the animals (Male: $n=22 ;$ Female: $n=31$ ).

\begin{tabular}{|c|c|c|c|c|c|c|}
\hline Age & No & $\begin{array}{c}\mathrm{Ni} \\
\left(\mu \mathrm{g} \mathrm{mL}^{-1}\right)\end{array}$ & $\begin{array}{c}\mathrm{Pb} \\
\left(\mu \mathrm{g} \mathrm{mL}^{-1}\right)\end{array}$ & $\begin{array}{c}\mathrm{Sr} \\
\left(\mu \mathrm{g} \mathrm{mL}^{-1}\right)\end{array}$ & $\begin{array}{c}\mathrm{Al} \\
\left(\mu \mathrm{g} \mathrm{mL}^{-1}\right)\end{array}$ & $\begin{array}{c}V a \\
\left(\mu \mathrm{g} \mathrm{mL}^{-1}\right)\end{array}$ \\
\hline$<5$ & 16 & $0.09 \pm 0.02$ & $0.08 \pm 0.02^{\mathrm{a}}$ & $0.25 \pm 0.02^{\mathrm{a}}$ & $0.71 \pm 0.04$ & $0.2 \pm 0.00$ \\
\hline $5-10$ & 26 & $0.11 \pm 0.01$ & $0.09 \pm 0.00^{\mathrm{b}}$ & $0.27 \pm 0.02^{\mathrm{a}}$ & $0.69 \pm 0.03$ & $0.2 \pm 0.00$ \\
\hline$>10$ & 11 & $0.1 \pm 0.01$ & $0.1 \pm 0.00^{c}$ & $0.20 \pm 0.07^{b}$ & $0.75 \pm 0.04$ & $0.2 \pm 0.00$ \\
\hline
\end{tabular}

Values that have a different superscript $(a, b, c)$ differ significantly from each other $(P<0.05)$.

Table 2: Concentrations ( $\mu \mathrm{g} / \mathrm{ml}$ ) of strontium ( $\mathrm{Sr})$, aluminum ( $\mathrm{Al})$, vanadium $(\mathrm{Va})$, nickel $(\mathrm{Ni})$ and lead $(\mathrm{Pb})$ in the serum of horses, depending on the age 
Citation: Nazifi S, Eskandarzade N, Khosravi M, Haddadi M, Rahsepar M (2017) Serum Concentrations of Strontium, Lead, Nickel, Vanadium and Aluminum in Horses. J Vet Sci Technol 8: 457. doi: 10.4172/2157-7579.1000457

alfalfa which is in equine diet the importance of evaluating this element in these animals is evident. However, reference values of blood $\mathrm{Ni}$ concentrations were not common in the literature and no toxicity studies were identified for horses. Besides, according to the European Food Safety Authority, contribution of foods of animal origin with high exposure to $\mathrm{Ni}$ to human diet is not insignificant [25]. In the present study, there is no significant difference in Ni concentration in all of the groups and the different age and sex studied here did not influence the contents of this element $(\mathrm{P}>0.05)$. This was the same as the findings revealed by Asano et al. [23] who reported that there was no age dependent correlation in Ni concentration of mane hair in male and female racing horses. In present study, the mean serum $\mathrm{Ni}$ concentration in 53 horses was $(0.10 \pm 0.08) \mu \mathrm{g} / \mathrm{ml}$ which was higher than the values reported by De Souza et al. [24] $(0.006 \mu \mathrm{g} / \mathrm{ml})$.

\section{Vanadium (V)}

Vanadium and related compounds are known to exert potent toxic effects on a wide variety of biological systems mediated by oxygenderived free radicals [26]. Concentration of this element in blood was the most suitable indicator of the body burden and was better tolerated by small animals including rats and mice than by larger animals, such as horses [27]. Acute toxicity value for vanadium is considered highly species-dependent $[28,29]$. Reference value of blood $\mathrm{V}$ concentration was not common in the literature. Based on Tables 1 and 2, difference in age and sex had no significant influence on vanadium status and there was no age-related correlation in vanadium concentration between groups $(\mathrm{P}>0.05)$.

\section{Aluminum (Al)}

Aluminium was classified as metalloestrogens because it increased estrogen-related gene expression in human breast cancer cells cultured in the laboratory [30]. In our investigation the contents of this toxic metal in the blood analyzed was not influenced by sex and age, therefore, there was no age-related correlation in $\mathrm{Al}$ concentration $(\mathrm{P}>0.05)$ which was in agreement with an investigation performed by Asano et al. [23] who reported that there was no age-dependent correlation in $\mathrm{Al}$ concentration of mane hair in male and female racing horses. In present study, the mean serum $\mathrm{Al}$ concentration in 53 horses was $(0.71 \pm 0.16) \mu \mathrm{g} / \mathrm{ml}$ which was lower than the values reported by Asano et al. [23] (64.5 \pm 77.0$) \mu \mathrm{g} / \mathrm{g}$ in the mane hair of horses.

\section{Conclusion}

We concluded that contamination of blood of horse by lead depends on the age of these animals although further investigations are needed to confirm this hypothesis.

\section{Acknowledgments}

The authors would like to thank the Research Council of Shiraz University and School of Veterinary Medicine, Shiraz University for financial and technical support of this study.

\section{Funding}

This study was funded by Shiraz University (Grant number: 71-GR-VT-5).

\section{Conflict of Interest}

The authors declare that they have no conflicts of interest.

\section{References}

1. Buttice C (2015) Nickel compounds. In: Colditz GA. The SAGE encyclopedia of cancer and society (second edition) SAGE publications, Inc., pp: 828-831.

2. Costa M, Sutherland JF, Peng W, Salnikov K, Broday L, et al. (2002) Molecular biology of nickel carcinogenesis. Mol Cell Biochem 222: 205-211.
3. Samal S, Mishra C (2011) Significance of Nickel in Livestock Health and Production. Int J Agro Vet Med Sci 5: 349-361.

4. Tabinda AB, Zafar S, Yasar A, Munir S (2013) Metals Concentration in Water Fodder, Milk, Meat, Blood, Kidney and Liver of Livestock and Associated Health Impacts by Intake of Contaminated Milk and Meat. Pakistan J Zool 45: 1156-1160.

5. Ciobanu C, Slencu BG, Cuciureanu R (2012) Estimation of dietary intake of cadmium and lead through food consumption. Rev Med Chir Soc Med Nat lasi 116: 617-623.

6. Kucera E (1988) Dogs as indicators of urban lead distribution. Environ Monit Assess 10: 51-57.

7. Kozak M, Kralova E, Sviatko P, Bilek J, Bugarsky A (2002) Study of the content of heavy metals related to environmental load in urban areas in Slovakia. Bratisl Lek Listy 103: 231-237.

8. Kapron B, Nowakowicz-debek B, Wnuk W, Martyna J, Saba L, et al. (2010) Effect of living conditions on heavy metal contents in Polish Konik horses coat hair and blood serum. Ochr Oerod Zas Nat 44: 66-71.

9. Pourjafar M, Badiei KH, Shakhse-Niaie M (2008) Horse Hair as an Indicator of $\mathrm{Pb}$ Pollution Around Shiraz Oil Industry Iran. J Environ Sci Technol 1: 42-46.

10. Topczewska J (2012) Effects of seasons on the concentration of selected trace elements in horse hair. J Cent Eur Agric 13: 671-680.

11. Topczewska J, Krupa W (2013) Influence of horse breed and housing system on the level of selected elements in horse's hair. J Elem 18: 287-295.

12. Pablack N, Mainzer B, Lahrssen-Wiederholt $M$, Schafft $H$, Palavinskas $R$, et al. (2014) Concentrations of strontium, barium, cadmium, copper, zinc, manganese, chromium, antimony, selenium and lead in the equine liver and kidneys. Springer Plus 3: 343-353.

13. ATSDR (Agency for Toxic Substances and Disease Registry). Public Health Statement: Strontium. Cdc.gov. Agency for Toxic Substances and Disease Registry, 2016.

14. Shagina NB, Bougrov NG, Degteva MO, Kozheurov VP, Tolstykh El (2006) An application of in vivo whole body counting technique for studying strontium metabolism and internal dose reconstruction for the Techa River population. $J$ Physics 41: 433-440.

15. Lemos RA, Driemeier D, Guimarães EB, Dutra IS, Mori AE, et al. (2004) Lead poisoning in cattle grazing pasture contaminated by industrial waste. Vet Hum Toxicol 46: 326-328.

16. Palacios $\mathrm{H}$, Iribarren I, Olalla MJ, Cala V (2002) Lead poisoning of horses in the vicinity of a battery recycling plant. Sci Total Environ 290: 81-89.

17. Rodriguez-Estival J, Barasona JA, Mateo R (2012) Blood Pb and $\delta-A L A D$ inhibition in cattle and sheep from a Pb-polluted mining area. Environ Pollut 160: 118-124.

18. Dey S, Dwivedi SK (2004) Lead in blood of urban Indian horses. Vet Hum Toxicol 46: 194-195.

19. Liu ZP (2003) Lead poisoning combined with cadmium in sheep and horses in the vicinity of non-ferrous metal smelters. Sci Total Environ 309: 117-126.

20. Marcal WS, Villegas-Navarro A, Nascimento MRL, Guerra AP, Fujihara CJ, et al. (2003) Bovinos e eqüinos como bioindicadores da poluiçao ambiental. Rev Brasil Ciencia Vet 10: 16-20.

21. Gilman A (1991) Heavy metals and their antagonists. In: The pharmacological bases of Clocks. Eds. Guanabara Koogan, Rio de Janeiro, pp: 1061-1065

22. Rudy M (2009) Correlation of lead, cadmium and mercury levels in tissue and liver samples with age of cattle. Food Addit Contam Part A Chem Anal Control Expo Risk Assess 26: 847-853.

23. Asano R, Suzuki K, Otsuka T, Otsuka M, Sakurai H (2002) Concentrations of toxic metals and essential minerals in the mane hair of healthy racing horses and their relation to age. J Vet Med Sci 64: 607-610.

24. De Souza MV, Ferreira Fontes MP, Alves Fernandes RB (2014) Heavy metals in equine biological components. R Bras Zootec 43: 60-66.

25. EFSA CONTAM Panel (EFSA Panel on Contaminants in the Food Chain) (2015) Scientific Opinion on the risks to animal and public health and the environment related to the presence of nickel in feed. Eur Food Safety Authority J 13: 4074-4076. 
Citation: Nazifi S, Eskandarzade N, Khosravi M, Haddadi M, Rahsepar M (2017) Serum Concentrations of Strontium, Lead, Nickel, Vanadium and Aluminum in Horses. J Vet Sci Technol 8: 457. doi: 10.4172/2157-7579.1000457

26. Aureliano M, Crans DC (2009) Decavanadate and oxovanadates: Oxometalates with many biological activities. J Inorg Biochem 103: 536-546.

27. WHO (World Health Organisation) (1988) Vanadium. Environmental Health Criteria 81. World Health Organization Geneva.

28. Hudson TGF (1964) Vanadium: Toxicology and biological significance. In: Browning E (ed.), Elsevier Monographs on Toxic Agents, Amsterdam, Elsevier Publishing Company, pp: 67-78.
29. Kucera J, Lener J, Mnukova J, Bayerova E (1998) Vanadium exposure tests in humans: Hair, nails, blood, and urine. In: Nriagu JO (ed.), Vanadium in the environment. Part 2: Health effects, New York, John Wiley \& Sons, pp: 55-73.

30. Darbre PD (2006) Metalloestrogens: an emerging class of inorganic xenoestrogens with potential to add to the oestrogenic burden of the human breast. J Appl Toxicol 26: 191-197. 